\title{
Study on Customer Experience Dimension Based on Online Shopping reviews of Ml's Products
}

\author{
Lin Wang ${ }^{1,2,{ }^{*}}$, Huijie Tang ${ }^{1,2}$, Dong Liu ${ }^{1,2}$ and Caiyan Xing ${ }^{1,2}$ \\ ${ }^{1}$ School of Business and Management, North eastern University, Shenyang 110819, China \\ ${ }^{2}$ School of Management, North eastern University at Qinhuangdao, Qinhuangdao 066004, China \\ Corresponding Email: wanglin05vip@163.com
}

\begin{abstract}
This study has selected sorts of comments about MI's products from its customers' as research objects, then we used the theory of Rooting to analyze those objects, and explored the Customer Experience Dimensions' type, characteristics and the way to impact others. The results come as follows: First of all, the Customers Experience Dimensions are consisted of nine major categories defined as Value Perception Experience, Sensory Experience, Quality Assurance Experience, Parts Experience, Purchase Experience, Service Experience, Brand Comparison Experience, Compensating Experience, Brand Reliance Experience respectively. Secondly, we put these nine major categories above all to compare the conclusions with the previous research, then we analyzed and integrated them, and finally obtained seven major categories containing Purchasing Website, Product Rendering, Delivery Experience, Transaction Convenience, Safety and Security, Brand Reliance, Marketing Communications respectively. In addition, we have conducted a further investigation to draw three types about the Customer Experience named Function Experience, Purchasing and Service Experience, and Brand Experience. Last but not the least, this paper has definitely provided the basis theory of how does the Customer Experience affect the Brand Loyalty for future research, as well as guided a definite orientation.
\end{abstract}

\section{Introduction}

With the creation of MI and the rapid development of the recent six years, a lot of small brands have begun to rise in the field of mobile digital industry, follow the various models of MI. So how to further improve the loyalty of MI users becomes increasingly important. According to the comprehensive analysis of documents and the data collected by questionnaire, we find the elaboration about the customer experience dimension is not perfect. Therefore, the specific research on the customer experience dimensions has an important guiding significance for the enterprise.

\section{Theoretical review}

Although the customer experience is developing, there is still not a uniform definition about it until now. Considering that the process of consumption involves experience, Lofman divided the customer experience into 6 dimensions: thought, emotion, feeling, scene, action and evaluation [1]. Pine II and James $\mathrm{H} \cdot$ Gilmore divided customer experience into Education, Entertainment, Escape and Aesthetic [2]. Josko Brakus divided customer experience into 5 dimensions from cognitive theory. They're Emotion, Intelligence, feeling, social communication and body [3] .

Besides the overseas scholars have studied the customer experience from various angles, domestic scholars also put forward some different views.

Chen Jian Xun thought customer experience should be divided by the level of warm when consumers were shopping. From negative experience to height experience, there are No experience, Low-degree experience and Moderate experience [4]. Song Wei divided B2C customer experience into 3 dimensions: Brand, Emotion and Function[5]. The specific topic of each dimension is shown in Table 1. 
Table 1. The Dimensions of customer experience.

\begin{tabular}{|c|c|c|}
\hline Dimension & Element & Measurement \\
\hline \multirow{2}{*}{$\begin{array}{l}\text { Brand } \\
\text { Experience }\end{array}$} & Brand Building & $\begin{array}{l}\text { The experience of brand names, brand identity, brand reputation and brand } \\
\text { awareness }\end{array}$ \\
\hline & $\begin{array}{l}\text { Marketing } \\
\text { Communication }\end{array}$ & The experience of sales and advertisement \\
\hline \multirow{2}{*}{$\begin{array}{l}\text { Emotion } \\
\text { Experience }\end{array}$} & Relax & Feel relaxed and alleviate the pressure and trouble when experience \\
\hline & Pleasure & Feel pleased or excited and bring surprise when experience \\
\hline \multirow{3}{*}{$\begin{array}{l}\text { Function } \\
\text { Experience }\end{array}$} & Website Experience & $\begin{array}{l}\text { The experience of page design of website, product information, site speed and } \\
\text { stability, he convenience of browse and purchase, security mechanism }\end{array}$ \\
\hline & Product Experience & The experience of the price, quality, package and kinds of product \\
\hline & Service Experience & $\begin{array}{c}\text { The experience of pre-sale service, after-sale service, logistic service, paying } \\
\text { and personalized service }\end{array}$ \\
\hline
\end{tabular}

\section{Research method}

\subsection{Sample selection}

The sample in this research comes from the comments put forward by online purchasers of MI. In the process of sample's data collection, we mainly adopt the following methods. First of all, formal researching channel is needed, which means we collect assessments of MI users through formal channels. Secondly, the comments we collect must be both comprehensive and focused. Thirdly, it is significant to ensure the representativeness of sample as well as the randomness of comments. Lastly, we neither add any personal subjective factors nor modify any original users' comments in the process of entire collection.

\subsection{Theoretical sampling}

When using the above methods to do our collection, we have got 1742 messages of comments on purchasing. Moreover, in the stage of data organization, We have got 870 pieces of effective comments, which is the basis of our following analysis.

\subsection{Grounded theory research method}

Our research is on account of the criteria and the process of grounded theory, research tool is selected from ROST Content Mining, a content mining software system, designed by professor Shen Yang. As shown in Figure.1. 


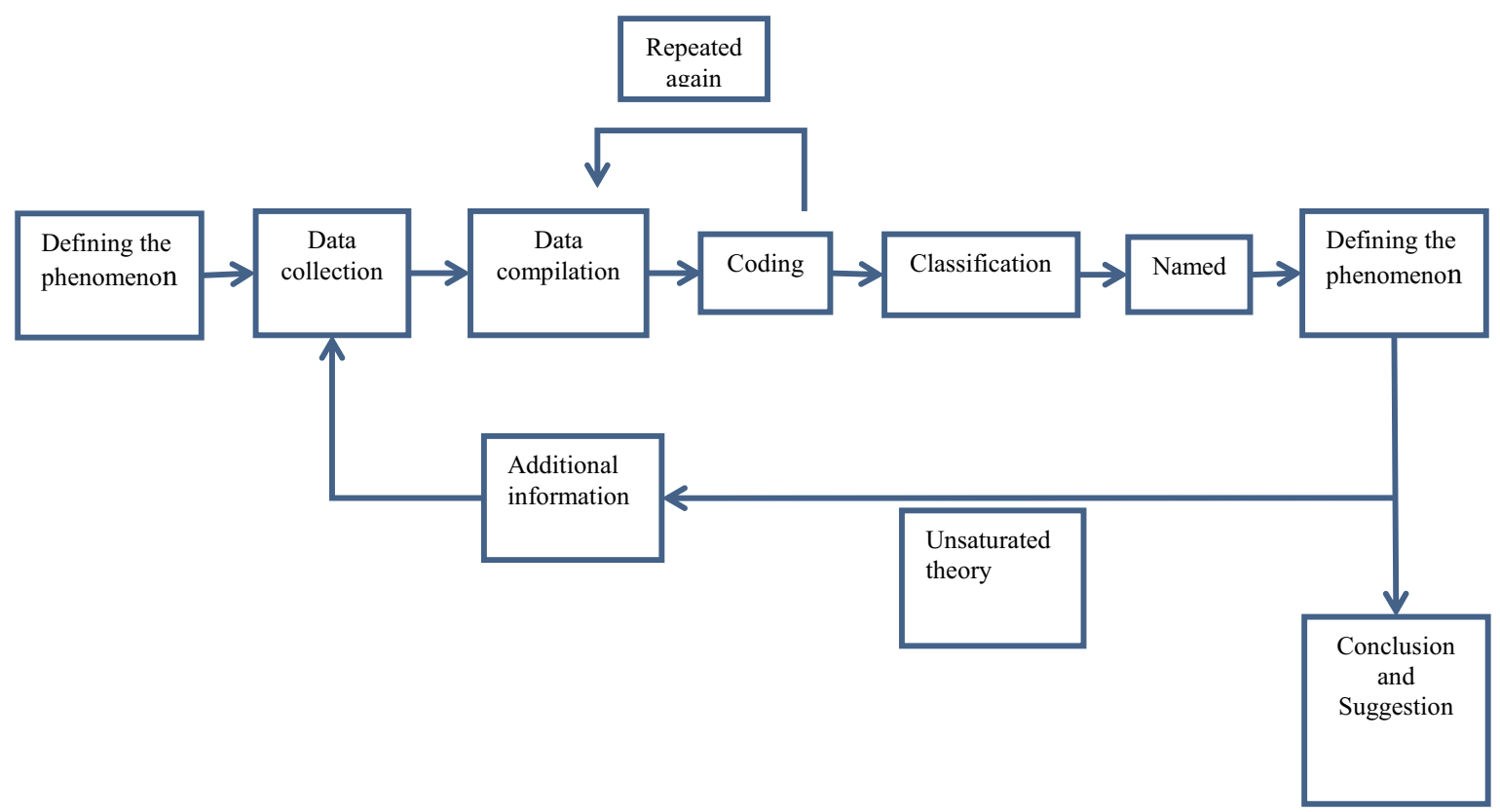

Fig. 1. The standard and process of Grounded theory.

\section{Research result}

\subsection{Open code}

In this section we will encode the original statement openly. Then, we form 25 categories, as shown in Table 2.

Table 2. Preliminary coding categories table.

\begin{tabular}{|c|c|c|c|c|}
\hline ID & Category & $\begin{array}{l}\text { Annotation } \\
\text { (article) }\end{array}$ & percentage & Typical source statements ( original concept ) \\
\hline N01 & Satisfaction & 113 & $12.99 \%$ & Put it down ; I am quite satisfied \\
\hline N02 & Customer service experience & 96 & $11.03 \%$ & Is patient ; It's why eat cat customer service \\
\hline N03 & Relation between clues & 82 & $9.43 \%$ & Help colleagues to buy ; For my father bought it \\
\hline N04 & Buying experience & 65 & $7.47 \%$ & $\begin{array}{l}\text { Rob times didn't get the } 4 \mathrm{G} \text { version of the move } \\
\text { It's hard to take }\end{array}$ \\
\hline N05 & Logistics experience & 58 & $6.67 \%$ & $\begin{array}{l}\text { Express fast ; The delivery speed of the slowest } \\
\text { ever }\end{array}$ \\
\hline N06 & Comparing experiences & 48 & $5.52 \%$ & $\begin{array}{l}\text { Wins on price is not high, the system works a little } \\
\text { better than Huawei ; The strongest signal is not red } \\
\text { rice }\end{array}$ \\
\hline N07 & $\begin{array}{l}\text { Experience product } \\
\text { attributes }\end{array}$ & 47 & $5.40 \%$ & Feels good $;$ Not press \\
\hline N08 & Brand perception & 42 & $4.83 \%$ & Millet mobile phone is good; Shop big guests \\
\hline N09 & Accessories gift experiences & 30 & $3.45 \%$ & $\begin{array}{l}\text { Nothing was sent, and sent a shell with foil, at } \\
\text { least ; } \\
\text { Buy back even the headphone cable is not open }\end{array}$ \\
\hline N10 & Payment experience & 26 & $2.99 \%$ & $\begin{array}{l}\text { The address to fill a fault, do not give change; } \\
\text { Took a couple of things, why should a single pay } \\
\text { the freight }\end{array}$ \\
\hline N11 & Return experience & 25 & $2.87 \%$ & $\begin{array}{l}\text { Please return they refused to apply ; Buying the } \\
\text { wrong type of refunds but it was too difficult }\end{array}$ \\
\hline
\end{tabular}




\begin{tabular}{|c|c|c|c|c|c|}
\hline N12 & & $\begin{array}{l}\text { Experience of product } \\
\text { defects }\end{array}$ & 24 & $2.76 \%$ & $\begin{array}{l}\text { Bought } 4 \mathrm{M} \mathrm{4} \text {, double } 11 \text { split ; The back of the } \\
\text { phone has received scratches }\end{array}$ \\
\hline N13 & \multicolumn{2}{|r|}{ Product feature experience } & 24 & $2.76 \%$ & Serious sound, no video;Sound good \\
\hline N14 & \multicolumn{2}{|c|}{ Value for money experience } & 24 & $2.76 \%$ & Value for money ; Price / performance king \\
\hline N15 & \multicolumn{2}{|r|}{ Brand loyalty-aware } & 23 & $2.64 \%$ & $\begin{array}{l}\text { Buy millet things, has become a habit ; From M } 1 \\
\text { to M } 4\end{array}$ \\
\hline & \multicolumn{2}{|r|}{$\begin{array}{l}\text { Exchange } \\
\text { experiences }\end{array}$} & 21 & $2.41 \%$ & $\begin{array}{c}\text { Order Shun Feng Express, so why go after } \\
\text { replacement post ; Replacement of the speed is } \\
\text { very fast }\end{array}$ \\
\hline & N17 & $\begin{array}{l}\text { Quality of } \\
\text { Experience }\end{array}$ & 21 & $2.41 \%$ & $\begin{array}{c}\text { Cargo is true; control, sooner or later, nobody } \\
\text { would buy it }\end{array}$ \\
\hline & N18 & $\begin{array}{l}\text { Rice injury } \\
\text { experience }\end{array}$ & 17 & $1.95 \%$ & $\begin{array}{c}\text { Loyalty rice noodles have a problem, customer } \\
\text { service has been not to answer; For the millet } \\
\text { consumed all }\end{array}$ \\
\hline \multicolumn{2}{|r|}{ N19 } & experience & 17 & $1.95 \%$ & $\begin{array}{l}\text { Packaged very carefully and tightly ; The product } \\
\text { in a Fedex box, not securely fastened }\end{array}$ \\
\hline & N20 & $\begin{array}{l}\text { Accessories } \\
\text { experience }\end{array}$ & 16 & $1.84 \%$ & Bad cable ; Cable cannot be recharged \\
\hline & $\mathrm{N} 21$ & $\begin{array}{l}\text { Purchase channels } \\
\text { experience }\end{array}$ & 15 & $1.72 \%$ & $\begin{array}{c}\text { It's hard to get the official website ; Flagship store } \\
\text { quality is absolutely reliable! }\end{array}$ \\
\hline \multicolumn{2}{|r|}{ N22 } & $\begin{array}{l}\text { Graphic describes } \\
\text { the experience }\end{array}$ & 14 & $1.61 \%$ & $\begin{array}{c}\text { Prettier than the picture; I don't feel so nice in the } \\
\text { picture }\end{array}$ \\
\hline \multicolumn{2}{|r|}{$\mathrm{N} 23$} & $\begin{array}{l}\text { Risk Perception } \\
\text { experience }\end{array}$ & 10 & $1.15 \%$ & $\begin{array}{l}\text { Broken screen cannot buy the official website of } \\
\text { insurance ; Don't see broken screen when buying } \\
\text { insurance option, there is no hint to buy! }\end{array}$ \\
\hline \multicolumn{2}{|r|}{$\mathrm{N} 24$} & $\begin{array}{l}\text { Promoting sales } \\
\text { experience. }\end{array}$ & 7 & $0.80 \%$ & $\begin{array}{l}\text { Forget to use coupon, unhappy ; A \$20 coupon } \\
\text { when you buy useless }\end{array}$ \\
\hline \multicolumn{2}{|r|}{$\mathrm{N} 25$} & $\begin{array}{l}\text { Turn powder } \\
\text { experience }\end{array}$ & 5 & $0.57 \%$ & $\begin{array}{l}\text { The first transfer from Apple powder bought millet } \\
\text { mobile phone; You don't have to buy Apple, good } \\
\text { affordable price }\end{array}$ \\
\hline
\end{tabular}

\subsection{Spindle coding}

Based on the original statement and part of the document definition above, we have these categories categorized into 9 categories and defined them, as shown in Table 3.

Table 3. Table of 9 main categories.

\begin{tabular}{|c|c|c|}
\hline $\begin{array}{l}\text { Fundamental } \\
\text { category }\end{array}$ & Correspondence category & Meaning of category \\
\hline \multirow{3}{*}{$\begin{array}{l}\text { Value perception } \\
\text { experience }\end{array}$} & Product function experience & $\begin{array}{l}\text { The use of hardware and software products, such as the use of } \\
\text { feelings }\end{array}$ \\
\hline & $\begin{array}{l}\text { Cost performance } \\
\text { experience }\end{array}$ & $\begin{array}{c}\text { The comparison of the performance of the product or service, the } \\
\text { price matching degree }\end{array}$ \\
\hline & Promotion experience & $\begin{array}{l}\text { On the way of brand sales, profits, limited coupons to attract } \\
\text { customers when purchasing experience }\end{array}$ \\
\hline \multirow{3}{*}{$\begin{array}{l}\text { Perceptual } \\
\text { experience }\end{array}$} & $\begin{array}{l}\text { Comparison of picture and } \\
\text { text description }\end{array}$ & $\begin{array}{l}\text { Perception of the actual situation of the product or service and the } \\
\text { picture and text comparison }\end{array}$ \\
\hline & Product attribute experience & $\begin{array}{l}\text { The use of product configuration, parameters, process and other } \\
\text { aspects of the experience }\end{array}$ \\
\hline & Packaging experience & $\begin{array}{l}\text { In the receipt of goods, the packaging of the product, the exquisite } \\
\text { degree of perception }\end{array}$ \\
\hline \multirow{2}{*}{$\begin{array}{l}\text { Quality assurance } \\
\text { experience }\end{array}$} & Quality experience & The quality of the product to buy the environment, genuine feeling \\
\hline & Risk perception experience & $\begin{array}{l}\text { The product accident insurance purchase, return shipping fee } \\
\text { dispute feeling }\end{array}$ \\
\hline $\begin{array}{l}\text { Accessories } \\
\text { experience }\end{array}$ & $\begin{array}{l}\text { Experience of } \\
\text { giving away }\end{array}$ & $\begin{array}{l}\text { In the purchase of the main products, the feelings of the business as } \\
\text { a gift to other parts of the behaviour }\end{array}$ \\
\hline
\end{tabular}




\begin{tabular}{|c|c|c|}
\hline & Accessories experience & $\begin{array}{l}\text { In addition to the purchase of the main products, the use of free } \\
\text { accessories for the feeling }\end{array}$ \\
\hline \multirow{2}{*}{ Buying experience } & $\begin{array}{l}\text { Purchasing channel } \\
\text { comparative experience }\end{array}$ & The comparison of the different channels to buy the brand products \\
\hline & Panic buying experience & $\begin{array}{l}\text { Feelings of the brand by letting users buy the way to allocate } \\
\text { existing products }\end{array}$ \\
\hline \multirow{5}{*}{ Service experience } & $\begin{array}{l}\text { Customer service } \\
\text { experience }\end{array}$ & $\begin{array}{l}\text { Customer service recovery rate, processing efficiency, service } \\
\text { attitude and logistics speed, attitude }\end{array}$ \\
\hline & Logistics experience & $\begin{array}{l}\text { On the brand's courier service attitude, as well as the delivery speed } \\
\text { and other aspects of the experience }\end{array}$ \\
\hline & Exchange experience & $\begin{array}{l}\text { After receiving the goods are not satisfied, to apply for a } \\
\text { replacement, replacement of a series of process experience }\end{array}$ \\
\hline & Return experience & $\begin{array}{l}\text { After receiving is not satisfied with the product, for the application } \\
\text { to return, return and a series of processes, such as the feeling }\end{array}$ \\
\hline & Payment experience & $\begin{array}{l}\text { In the purchase order, payment of postage, fill in the address, and } \\
\text { other aspects of the experience }\end{array}$ \\
\hline \multirow{3}{*}{$\begin{array}{l}\text { Brand comparative } \\
\text { experience }\end{array}$} & Perceived brand awareness & $\begin{array}{l}\text { Users of the brand has a certain understanding or awareness of the } \\
\text { use of products }\end{array}$ \\
\hline & Comparative experience & $\begin{array}{l}\text { Through different brands, the same brand of different series or the } \\
\text { same series of different models of the use of product experience } \\
\text { comparison }\end{array}$ \\
\hline & $\begin{array}{l}\text { Powder transfer } \\
\text { experience }\end{array}$ & $\begin{array}{l}\text { From other brands of loyal users to the brand loyalty user } \\
\text { experience }\end{array}$ \\
\hline \multirow{2}{*}{$\begin{array}{l}\text { Compensation } \\
\text { experience }\end{array}$} & Rice injury experience & $\begin{array}{l}\text { As a brand loyal user, because there is no expected service or } \\
\text { product experience feelings }\end{array}$ \\
\hline & Product defect experience & $\begin{array}{l}\text { Experience in product defects, defects, functional / design defects, } \\
\text { etc. }\end{array}$ \\
\hline \multirow{3}{*}{$\begin{array}{l}\text { Brand dependent } \\
\text { experience }\end{array}$} & Satisfying experience & $\begin{array}{l}\text { A comprehensive evaluation of the satisfaction of product } \\
\text { identification, complaints, complaints and so on. }\end{array}$ \\
\hline & Relationship experience & $\begin{array}{l}\text { Feelings of people who have a certain social relationship with } \\
\text { buyers to buy the brand's products }\end{array}$ \\
\hline & Brand loyalty perception & As a brand loyal users in the purchase process of a series of feelings \\
\hline
\end{tabular}

\subsection{Determination of the dimensions of customer experience}

This paper compares previous results with 9 experience categories in Table 3, analysis and integrates them, we get customer shopping experience. They are functional experience, buying and service experience and brand experience. Specific such as Table 4.

Table 4. Determination of the dimensions of customer experience.

\begin{tabular}{|c|c|c|}
\hline $\begin{array}{c}\text { Customer experience } \\
\text { dimensions }\end{array}$ & Main category & Subcategory \\
\hline \multirow{5}{*}{ Feature experience } & \multirow{2}{*}{ Buy website } & Web site design \\
\hline & & Classified display \\
\hline & \multirow{3}{*}{ Product rendering } & Product quality \\
\hline & & Product price \\
\hline & & Product information \\
\hline \multirow{9}{*}{$\begin{array}{c}\text { Purchase and service } \\
\text { experience }\end{array}$} & \multirow{3}{*}{ Delivery experience } & Graphic description \\
\hline & & Packaged experiences \\
\hline & & Accessories gift experiences \\
\hline & \multirow{3}{*}{$\begin{array}{l}\text { Transaction } \\
\text { convenience }\end{array}$} & Buying experience \\
\hline & & Ordering experience \\
\hline & & Customer service experience \\
\hline & \multirow{3}{*}{ Safety and security } & Logistics experience \\
\hline & & Return and exchange experience \\
\hline & & Accident insurance \\
\hline \multirow{2}{*}{ Brand experience } & \multirow{2}{*}{ Brands rely on } & Relationship experiences \\
\hline & & Brand experience \\
\hline
\end{tabular}




\begin{tabular}{cc}
\hline $\begin{array}{c}\text { Marketing } \\
\text { communications }\end{array}$ & Promotions \\
${\text { Advertisement }} \\
{\hline}$
\end{tabular}

\subsection{Theoretical saturation test}

Usually, in qualitative research credible degree is an important measure standard used to evaluate the quality [6]. At the same time, the validity is also used to evaluate the quality [6]. At the same time, the validity is also used to evaluate a measure of the quality of qualitative research, which can reflect the online scene clues, etc. We will use the Raw Material Inspection and Inspection and Feedback Method to verify the effectiveness of the model and the results of the study.

\subsubsection{The raw material inspection}

Concepts and relations are in return for the model review. That "concept" must be derived from the original data [7]. All of the selections of data in this paper are from MI's setting of formal channels for evaluation of the original users' information. It is effectively to ensure the information from the user's comments in the reliability of the dimensions of customer experience.

\subsubsection{The expert evaluation method}

Successively in the whole process of this research has four experts in the fields of Marketing and E-commerce, under their suggestions, eventually, we got the effective customer experience dimensions.

To sum up, using the Original Material Test, Expert Evaluation Method and the Research Results have good consistency and good validity. Therefore, this research is effective, credible and reliable.

\section{Discussion and conclusions}

In this study, we selected two dimensions of customer experience, which contain functional experience and service experience, into the purchase and service experience. In addition, this study can also develop the research, delivered by Song Wei, about dividing class on the dimensions of customer experience.

\subsection{Theoretical significance}

First of all, this study used the method of grounded theory to get customer experience dimensions: functional experience, buying and service experience, brand experience. These dimensions are constituted by seven main categories, which respectively are purchasing website, product, delivery and transaction convenience, security assurance, dependence on branding, marketing communications.

Secondly, the findings revealed a phenomenon in the period named as "experience economy" that product experience is a good way to understand a brand, what is more, a well customer experience is powerful for the brand loyalty. Therefore, according to the customer experience, we proposed the following recommendations derived from two aspects.

\subsubsection{Recommendation for Ml's products}

In addition to designing a more simple, comfortable MI's products purchased website with the products exhibition and the category clearly, the most important thing that MI should focus on is continuing produce the offerings with good quality, even making users to scream.

\subsubsection{Recommendation for service experience}

The company should promise that especially unblocking the process in snapping up, promising the snapping up is fair, and if the snapping up is not success, the company should make comfort measures, like sent comfort SMS. In terms of the customer's remedies, it is allowed that according to the times of customers' buying, the waiting time, the failure times and so on, to category different customer types with varying degrees of comfort measures.

\subsection{Limitations and future research directions}

There are also some limitations in this study, specific description comes as follows. Firstly, the size of sample in this study is limited, the validity of the results is limited and cannot exclude the influence of the external factors. Secondly, the dimensions of customer experience have been obtained through this research and these results can be seen as a guiding role to enhance the customer's brand loyalty for MI, but how does the customer experience influence the customer's brand loyalty are not well-known. 


\section{Acknowledgements}

This research is supported by funding of China's central university basic scientific research expenses Project No. N152304008.

This research is supported by funding of Northeastern University at Qinhuangdao in China, which Humanities and Social Sciences Key Project No. XNR201601.

\section{References}

1. A. Samuel, O. W. Fred, Q. Zhou, etc. A1 Transformation Leadership, Innovative Behavior, and Task Performance: Test of Mediation and Moderation Processes, 25, 1 (2012)

2. Joseph Pine II, James II. Gilmore. The experience economy. translated by XIAYELIANG(Beijing mechanical industry publishing house, 2008)

3. Joskol Brakes, A theory of consumer experiences (Columbia University, 2001)

4. CHENJIANXUN, Multiple levels of customer experience and prolong the life cycle of strategic choices (Statistics and decision making, 2005)

5. SONGWEI, B2CE-commerce customer experience impact on customer loyalty research (JINAN:SHANDONG University, 2012)

6. J.X. Wu, X.T Huang, Credit structure (Psychology Newspaper, 2012)

7. D. Trafimow, Considering Quantitative and Qualitative Issues Together (Qualitative Research in Psychology, 2014) 